\title{
방글라데시 원조 수원액 감소 및 Good Governance 부각
}

\section{I. 국제사회의 對방글라데시 원조액} 감소

ㅁ방글라데시 수원기관인 경제협력청(ERD: Economic Relations Division)은 2004 회계년도 (2003.7 2004.6)중 선진 원조국의 방글라데시 대 상 원조액이 이례적으로 감소, 10 억 3천만 달러에 그친 것으로 발표함.

- ERD에 따르면 총 수원액 10.3억 달러 가운데 6.9 억 달러(67\%)는 차관이고 3.4 억 달러(33\%) 는 무상원조로 구성되어 있으며, 이 같은 수원 규모는 지난 25 년의 수원역사 중 가장 적은 수 준임. 방글라데시의 수원액은 지난 89년 18억 달러를 최고로, 이후 감소세를 보여 왔으나 년 평균 15 억 달러 수준을 유지하여 왔음.

- 이 같은 원조액(Disbursement)은 당초 원조국 의 약속액(Commitment)과는 차이가 큰 것으 로, 2004년의 경우 공여 약속액이 17.2억 달러
였으나 이 가운데 6.7 억 달러는 미집행되었는 바, 이는 방글라데시의 비능률적이고 부패한 행정 에 기인하는 바가 큼. 즉 선진 원조기관들은 방 글라데시 정부관리들의 부패를 경험하며 개발 사업 지원시 더욱 투명하고도 엄격한 조건을 부 가하는 경향이 있으며 이는 관행상 적용하기 어 려운 경우가 많아 결과적으로 개발사업의 지연 또는 중단을 야기함.

- 국별 원조규모(집행액)를 보면, 세계은행이 2.2 억 달러로 방글라데시 최대의 공여자이며 $\mathrm{ADB}$ 1.7 억 달러, 영국 93 백만 달러, 일본 79 백만 달 러, 네델란드 40 백만 달러, $\mathrm{UNDP}$ 등 유엔기관 36 백만 달러, 독일 26 백만 달러 등임.

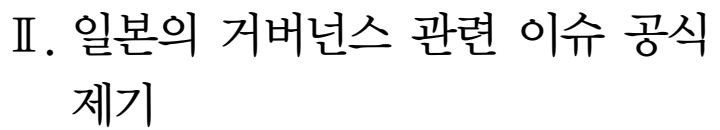
제기 
ㅁ한편, 일본 정부는 방글라데시 대상 원조사업의 효 과적 수행을 위하여 거버넌스 관련 이슈(행정의 비 효율성, 부패, 정치연루 등)를 공식 제기하였음. 그 간 서방 원조국들이 원조사업과 관련하여 지속적으 로 거버넌스 이슈(인권문제 포함)를 제기, 방글라데 시 정부와 불편한 관계를 유지한 데 반하여 일본 정 부는 이와 관련된 발언을 자제하여 왔음에 비추어 이와 같은 제기는 다소 이례적인 것으로 평가됨.

- 이는 일본의 원조사업(ODA) 예산이 축소되는 가운데 원조사업의 효율적 추진을 요구하는 여 론이 높아진 것을 반영한 것으로, 일본은 방글 라데시의 부패한 관료들이 입찰 조작 등을 통하 여 무자격자를 사업시행자로 선정, 결과적으로 사업의 지연 또는 실패를 야기하는 일들을 예방 하기 위한 조치로 분석됨.

- 일본은 방글라데시 최대의 원조 공여국으로, 1972년 이후 총 105.4 억 달러의 원조자금을 공 여하여 왔음(이 가운데 차관이 56 억 달러, 무상 45억 달러, 기술협력 4.4 억 달러임). 일본 정부 는 투입자금의 효과적 활용을 위하여 새로운 원 조정책을 구상중이며 주로, 민간부분 활성화, 거버넌스 개선, 교통, 전력 및 농업부문 인프라 구축, 인간 안전보장을 위한 재해원조 및 보건 위생, 기초교육, 환경부문 등의 개선을 목표로 하고 있음.

\section{III. 방글라데시 거버넌스 관련 최근 사례}

ㅁ상기 개발사업의 입찰과 관련한 정부의 부패는 사 전에 특정 입찰자와 공무원(정치인)이 연계하여 개 발 사업을 수주받는 방식이 일반적이며, 최근 사례 는 아래와 같음.

- 방글라데시 정부(내각 조달물자 위원회)는 6.18 방글라데시 Penchuganj 지역 복합 화력 발전 소(발전전력 90 메가와트) 사업시행자로 사업경 험이 없는 중국계 Harbin Power Engineering 사를 선정토록 승인한 바 있음.

- 동 발전소 설립사업 시행자 선정을 위한 입찰은 그간 6차례나 있었으나 방글라데시 전력청 (PDB:Power Developement Board)은 특별 조건을 제시하거나 특별한 이유 없이 입찰을 지 연, 선진국의 유력 입찰자들이 스스로 입찰 참 가를 포기하도록 영향력을 행사하였으며, 결과 적으로 지난 4 월의 7 차 입찰에서는 중국계 회사 만이 응찰하게 됨.

- 동 중국계 회사는 방글라데시 정부의 조달 규정 상 사업수행 경력(최소 10 년 이상) 등에서 자격 미달임에도 정부(조달위원회)는 규정을 위반하 면서 계약 체결(사업자 선정) 승인을 결정함.

- 이러한 결과는 방글라데시 정부의 유력자가 개 발사업을 빌미로 사업시행자와 부패고리를 형 성, 원조 자금을 유용하는 것으로 추정되며 결 과적으로 개발사업의 전망을 어둡게 하는 등 방 글라데시의 성장 잠재력을 갉아먹는 요인 중 하 나로 지적되어 옴.

[자료:주방글라데시 대사관] 